\title{
Insurgências marginais: as leis e o Estado na formação do teatro musical popular francês
}

\section{Denise Scandarolli}

Resumo: Este texto aborda o papel do Estado na estruturação dos gêneros franceses de teatro musical e tem como foco os teatros populares parisienses, oriundos das feiras urbanas, sua origem e trajetória até a definição das formas às quais as obras deveriam se adequar a fim de se oficializar como repertório de um teatro específico. Tem como objetivo, também, entender as regulamentações teatraise sua importância na especificação de gênero das obras de teatro musical francês, assim como as brechas deixadas pela lei, possibilitando o desenvolvimento dos teatros musicais populares, como o vaudeville e o opéra-comique.

Palavras-chave: História. Teatro Musical Francês. Estado.

Marginal Insurgencies: the laws and the state in the formation of the French musical theater

Abstract: This paper approaches the State's role in the structuring of the French music theater genres and focuses the popular Parisien theater, from urban fairs. Their origin and trajectory to the definition of the forms that the work should be adapted to officiate as a specific theater's repertoire. It also aims to understand the theatrical regulations and its importance for the genre specification of the French musical theater work as well as the gaps left by law enabling the development of the popular music theaters, the vaudeville and the opéra-comique.

Keywords: History. French Music Theater. State.

Uma questão bastante abordada ao se tratar da história do teatro lírico francês é que apenas alguns poucos artistas monopolizavam o teatro musical na corte de Luis XIV, como Jean-BatisteLully (1632-1687), músico nascido em Florença, mas que se consagrou na França como compositor oficial do Rei Sol, Philippe Quinault (1635-1688), 
dramaturgo e libretista francês e Thomas Corneille (1625-1709), jurista e também dramaturgo francês.

As principais obras de Lully foram feitas em parceria com Quinault e Corneille, eles dominavam a cena francesa e a linguagem das Tragédies Lyriques. No entanto, a supremacia de suas obras era condicionada ao controle que Luís XIV exercia sobre estes espetáculos, de tal maneira que se cerceava a atuação de outros autores e músicos nos teatros do país. Marin Marais (1656-1728) foi um dos artistas que sofreu com este sistema de privilégios. Gambista e compositor, ele atuava como músico do Palácio de Versailles, desde 1676, mas teve sua primeira Tragédie estreada apenas em 16932, logo após a morte de Lully e, consequentemente, após o fim de seu monopólio nos teatros franceses.

Assim como em outras cortes e casas aristocráticas, na França, durante o século XVII, o teatro musical era predominantemente um espetáculo da nobreza, simbolizando o seu requinte ao oferecer produções caras a um público seleto. Este panorama se modificou no decorrer do século XVIII, período em que houve um alargamento dos domínios do teatro musical para além dos muros dos palácios, em um processo de crescente demanda do público burguês por esse tipo de divertimento. Assim, essas obras passam dos teatros particulares da corte para teatros com plateia mais heterogênea e pagante. Apesar de não ser mais representada unicamente para a aristocracia, a força simbólica deste espetáculo se mantém, como hábitos superiores, e por

1 Tragédi eLyriqueou Tragédie en musique é o termo cunhado por Jean-Baptiste Lully para diferenciar o gênero de teatro musical francês daquele produzido na Itália, a Ópera. As principais Tragédies Lyriques compostas por Lully foram: Cadmus et Hermione (lib. Quinault) 1673; Alceste, ou le Triomphe d'Alcide (lib. Quinault) 1674); Thésée (lib. Quinault) 1675; Atys (lib. Quinault) 1676; Isis (lib. Quinault) 1677; Psyché (lib. Corneille e Fontenelle) 1678; Bellérophon (lib. Corneille, Fontenelle e Boileau) 1679; Proserpine (lib. Quinault) 1680; Persée (lib. Quinault) 1682; Phaéton (lib. Quinault) 1683; Amadis (lib. Quinault) 1684; Roland (lib. Quinault) 1685; Armide (lib. Quinault) 1686 e Achile et Polyxène (lib. Capistron) 1687. Lully ainda compôs comédies-ballets e ballets de cour.

${ }^{2}$ Alcide, libreto de Louis Lully, estreada em 1693. 
assim dizer, digno de distinção (BARTHÉLÉMY , 1990; SENNETT, 1988; TROTT, 2000).

$\mathrm{Na}$ França, o crescente número de espetáculos teatrais que começaram a ser apresentados fora da corte proporcionou uma mudança nos jogos de interesses, os quais insidiam diretamente na produção dos sentidos expostos em cena. A ampliação desses espetáculos para além dos muros do palácio real criou novos espaços de representação reivindicados pelos diversos grupos sociais pelos quais o público passou a ser formado. De um controle proveniente do "gosto" aristocrático, passa-se à necessidade de vigilância e cerceamento dos discursos representados nos teatros alocados nas cidades, ação praticada por duas vias, a subvenção do Estado e a censura (DARNTON, 2016; FABIANO, 2005; KOSELLECK, 1979; LEGRAND, 2002; SENNETT, 1988). Neste contexto, após a abertura de salas de espetáculo na cidade de Paris, as atenções versadas sobre esta arte se dividiram entre os dois teatros oficiais, o que dispunha do direito de representar apenas peças declamadas, a Comédie Française e o que dispunha do direito de colocar em cena somente peças inteiramente cantadas, a Académie Royale de Musique. De certa forma, a relação estabelecida entre a autorização de funcionamento das salas de espetáculo por parte do Estado e o repertório ao qual estas salas tinham direito foram de fundamental importância no desenvolvimento dos gêneros de teatro, na França, durante todo o século XVIII. Dentro desse contexto, o objetivo aqui é entender a trajetória do teatro musical popular e como essas imposições do Estado e os jogos de poder entre os teatros proporcionaram a criação de dois gêneros específicos de teatro musical, como espaço marginal, distinto da ópera italiana, da Tragédie lyrique e do grand opéra.

\section{Das margens dos teatros às margens historiográficas}


Durante o século XVIII, os espetáculos das feiras parisienses foram julgados como menores, por seu caráter popular, e não alcançaram reconhecimento nem legitimidade como arte teatral valorizada. O desprestígio destes espetáculos promovido pelas elites artísticas foi apenas uma das tentativas de silenciá-los, seguida de tantas outras tentativas de caráter oficial de por fim a suas apresentações. A historiografia sobre o teatro francês e a musicologia também os mantiveram solapados pela preponderância das narrativas sobre as trajetórias dos teatros oficiais, até meados dos anos de 1990 (LEGRAND, 2002), período em que alguns dos artistas provenientes desse teatro marginal foram redescobertos por pesquisadores acadêmicos, a exemplo de Jean-Philippe Rameau (1683-1764), AlainRené Lesage (1668-1747), Charles-Simon Favart (1710-1792).

O teatro musical francês enquanto sujeito histórico se encontra presente tanto em abordagens da História do Teatro quanto da Musicologia Histórica, com mais enfoque na primeira, por se tratar de espetáculo múltiplo (texto-música-cena), indo além dos domínios unicamente musicais.

No que diz respeito à historiografia do teatro francês do século XVIII, seu escopo se ampliou, a partir dos anos de 1930, deixando de tratar exclusivamente das obras e autores, passando a englobar problemáticas referentes à gestão e negócios teatrais, polícia dos teatros, construção de salas e composição do público. Este alargamento a novos sujeitos de pesquisa se deve, em grande parte, ao conceito de "vie théâtrale" formulado por Max Fuchs (1933), em sua obra La vie théâtral en province au XVII/e siècle.

Mas, foi durante os anos de 1980 que apareceram estudos mais abrangentes sobre o teatro francês do século XVIII. Impulsionados pelo Bicentenário da Revolução Francesa, os historiadores da França das Luzes e da Revolução tentaram inserir a história do espetáculo em uma história cultural que buscava explicar a grande transformação política do 
fim do século. Sendo assim, a noção do teatro do século XVIII elaborada por esses pesquisadores foi pouco a pouco enriquecida, alargada, até abranger a concepção de "teatros" e de "públicos" e não mais a noção apresentada no singular de um só teatro ou um só público (RAVEL, 2012). Neste mesmo caminho, os trabalhos mais recentes sobre o tema suscitam novas questões marcadas por duas vertentes historiográficas, a que segue as abordagens provenientes do termo de "Vie théâtrale" e aquela que se baseia na Nova História Cultural (RAVEL, 2012).

A expressão Vie théâtrale é formulada por Max Fuchs com base nos estudos de seu professor Gustave Lanson, nos quais ele distingue a história da literatura e aquela da vida literária, sendo uma o estudo da produção das obras e a outra sua difusão ao público (FUCHS, 1933). Fuchs propõe, por sua vez, o estudo de tudo o que se relaciona à representação dos textos dramáticos sobre a cena frente ao público e não apenas os textos em si. Os estudos de Fuchs, segundo Ravel (2012), são tidos como chave para outros trabalhos, como o de Henri Lagrave, autor de Le théâtre et lepublic à Paris de 1715 a 1750 (1972) e La viethéâtrale à Bordeaux des origines à nos jours (1985). Nestas obras, Legrave sustenta a ideia de que a vida teatral começa com a história das grandes e pequenas trupes de teatro, assim como com a história política e administrativa dos teatros, passando em seguida para o que ele denomina de "la vie des théâtres", abrangendo o espaço teatral e o público, além de tecer observações sobre o repertório, os comediantes, a produção e a crítica.

Outro trabalho que faz referência direta à obra de Fuchs é $L a$ vie théâtrale en France au XVIIle siècle, tese de Martine de Rougemont, defendida em 1982 e editada em 1988. Esta obra se coloca, em vários âmbitos, como uma obra inovadora, apesar de abordar amplamente a história do teatro em Paris, relegando os teatros da província para uma pequena parte do texto, como critica Ravel (2012). Por outro lado, o teatro parisiense apresentado por Martine de Rougemont não é nem limitado aos teatros privilegiados nem aos grandes escritores e suas 
obras. Várias de suas análises são concernentes aos teatros chamados menores, às apresentações privadas - o jogo de cena e a produção, o repertório assim como a crítica -, revelando que as obras teatrais do século XVIII se encontram em meio à expansão dos textos, das cenas, dos autores, dos comediantes e, sobretudo, do público (RAVEL, 2012).

$\mathrm{Na}$ argumentação de Rougemont, o crescimento econômico e material dos teatros, no período, não implica somente na aparição de uma indústria teatral, como havia mostrado Max Fuchs, mas sim, e sobretudo, em uma "teatralização do cotidiano" comum a muitas camadas sociais. Os lugares e formas de encontro com o teatro se multiplicam, pela circulação dos textos, mas também nos espaços públicos e nas residências privadas, no campo como na cidade. O papel do público é fundamental nessas análises que envolvem a criação de eventos teatrais durante o século XVIII (RAVEL, 2012). Todavia, o livro de Martine de Rougemont, como resultado, propõe uma visão enciclopédica da vida teatral de 1715 a 1789, fundada sobre a consciência de que é necessário buscar no público as fontes da vida teatral. Além disso, a metáfora da teatralização do cotidiano tinha sido usada por Richard Sennett em $O$ declínio do homem público, de 1974. Nesta obra, Sennett constrói sua argumentação sobre as mudanças das relações do indivíduo com o espaço público, utilizando-se, como analogia, a imagem estabelecida entre os espectadores e o teatro e as modificações desta relação ao longo do século XVIII, nas transformações das formas de teatralização do cotidiano.

O jogo argumentativo de Sennett, presente também no trabalho de Martine Rougemont, possibilitou novos caminhos de análise considerando as relações entre público e teatro, sociedade e tempo, historicizando as suas práticas. No que concerne à história do público espectador, que Martine de Rougemont coloca no centro de seus estudos, a tese de Jürgen Habermas, de 1962, sobre a espera pública como representante de uma dimensão do social atuando como 
mediadora entre o Estado e a sociedade, também tem grande presença nas abordagens da pesquisadora.

Apesar de tecer considerações pertinentes com base em discussões historiográficas correntes no período, o trabalho de Rougemont suscita alguns questionamentos, como os colocados por Jeffrey Ravel (2012), de que o trabalho carece de uma visão coerente do século XVIII, propondo uma articulação entre os múltiplos teatros, pois a vida teatral esboçada por Rougemont é, antes de tudo, a apresentação de vários mundos que, às vezes se misturam, às vezes permanecem isolados uns dos outros.

Este esboço proposto por Rougemont enquadra os teatros menores em um mundo subversivo e cuja percepção de sua atuação se apoia na exclusão posta em contraponto aos teatros principais. É uma análise baseada nas referências impostas a partir daqueles espaços de espetáculo já institucionalizados, ignorando as singularidades e a ação própria dos teatros menores. Rougemont toma as posturas de reação desses teatros como negação à norma vigente, acarretando em resultados não producentes e limitados à relação estabelecida entre eles e os teatros principais, esvaziando os significados próprios das obras produzidas pelos teatros menores e silenciando os resultados positivos de seu enfrentamento à norma.

A ruptura historiográfica do fim dos anos de 1980 proporcionou novos direcionamentos aos estudiosos da história do teatro, impulsionados pelas abordagens da História Cultural Francesa, da Nova Historia Cultural norte americana, com historiadores como Lynn Hunt, mais a convergência de teóricos franceses como Michel Foucault, da antropologia cultural e do aprofundamento do conceito de "mentalidades". A crítica dos estudos culturais se direciona à interpretação rígida e como unicidade do conceito de cultura e da interpretação simples na qual a cultura é apenas o reflexo da realidade social. Buscou-se, assim, mostrar os diversos meios de recepção e 
apropriação dos textos tanto impressos como manuscritos para os seus múltiplos leitores (BAKHTIN, 1965; BURKE, 1989; CHARTIER, 1988).

Em relação à história do século XVIII francês, esta corrente historiográfica possibilitou diversos estudos sobre os espetáculos, em obras como La fête révolucionnaire, de Mona Ozouf, publicado em 1976, e de Lynn Hunt, Politics, Culture, and Class in the French Revolution, de 1984.

O jogo político de confrontação entre espectadores e artistas teatrais (sejam eles compositores ou atores) nas salas de espetáculo passou a ser um problema consistente para as análises históricas. $\mathrm{O}$ lugar do espectador diante da representação do poder começou a ser questionado, em vários períodos, como nos teatros da corte do Rei Sol, durante a instabilidade do regime de 1789 a 1799, ou durante a Restauração, problematizando como o teatro dá forma aos conflitos políticos do século XVIII (BARA, 2001).

$\mathrm{Na}$ ocasião do Bicentenário da Revolução Francesa apareceram alguns livros consagrados ao tema, como o de Laura Mason, Singing the French Revolution: Popular Culture and Politics (1996) e o de James H Johnson, Listening in Paris: A cultural History Listening in Paris: A cultural History (1995). Este último ressalta o que o autor considera ser uma dupla modificação neste período: do público que passou a ser mais e mais silencioso, e a obrigação do público de se apresentar ao espetáculo de maneira mais diminuta. Outro trabalho com argumentação próxima é o de Jeffrey S. Ravel, The Contested Parterre: Public theater and French Political Culture, 1689-1791 (1999). O ponto convergente destes estudos é que o público do teatro deve ser visto nos termos das práticas do espectador dentro da sala de espetáculo e não nas origens sociais deste espectador.

No âmbito dos atos políticos do teatro, há ainda o trabalho de Sara Beam sobre o caráter político do riso, Laughig Matters: Farce and 
The Making of Absolutism in France (2007)3. Beam, apesar de abordar os teatros das feiras e dos boulevares, dá menor atenção ao gênero das obras e aos seus autores, priorizando os usos, as relações entre teatro e público e o lugar dos comediantes que buscavam uma forma de ganhar a vida em contraponto ao poder monárquico, cada vez mais consciente da força crescente da voz pública. É justamente a percepção do poder da voz pública o mote de pesquisa que liga os teatros e a política no contexto da Revolução4.

Apesar de alguns desses trabalhos abordarem os teatros populares, a atenção de todos eles está no potencial espacial dos mesmos, do local onde estes espetáculos aconteciam e na formação e força política de seu público. São poucos e recentes os estudos que buscam entender a função desses espetáculos como gênero teatral, o lugar das obras apresentadas em relação ao social e à representação do espectador, como pode ser visto nos estudos de RaphaëlleLegrand, Andréa Fabiano e Olivier Bara 5 .

Os teatros das feiras constituem um amplo campo de investigação ainda pouco ocupado. Seu papel político ativo, que durante o século XVIII tinha como representação a voz do público, bem como sua importância estética na esfera do teatro musical carecem de estudos. Com uma trajetória singular, o lugar marginal de origem desses espetáculos possibilitou que eles se transformassem em espaço de

3 Outros trabalhos anteriores sobre o tema são: Michèle Root-Bernstein, Boulevard Theater and Revolution in Eighteenth-Century Paris, Ann Arbor, UMI Research Press, 1984; Robert Isherwood, Farce and Fantasy: Popular Entertainment in Eighteenth-Century Paris, New York et Oxford, Oxford University Press, 1986; d'Isabelle Martin, Le Théâtre de / afoire : des tréteaux aux boulevards, Oxford, Voltaire Foundation, 2002; Françoise Rubellin.

4 Ver: Paul Friedland, Political Actors: Representative Bodies and Theatricality in the Age of the French Revolution, Ithaca et Londres, Cornell University Press, 2002.

5 Podemos citar trabalhos como: LEGRAND, Raphaëlle. Regards sur l'opéracomique: trois siècles de vie théâtrale. Paris: CNRS Editions, 2002; FABIANO, Andréa. La Querelle des Bouffons dans la vie culturelle française du XVIIle siècle. Paris: CNRS éditions, 2005; BARA, Olivier. Le théâtre de l'Opéra-comique sous la Restauration, Enquête autour d'un genre moyen. Olms: Hildeshim, 2001. 
criação, e as diversas sanções impostas pelas regras do Estado aos teatros, em espaço de transgressão.

\section{A lei que rege o teatro}

A vida teatral de Paris foi se definindo por meio das legislações e jurisprudências impostas pelo Estado. Não só o funcionamento dos teatros estava à mercê das regulamentações governamentais, mas as sanções, delimitações, extinção de espetáculos, foram cruciais no processo de definição de gêneros autorizados a serem postos em cena em teatros específicos. Na França, o desenvolvimento dos gêneros teatrais e como eles deveriam ser constituídos, como a ópera, o vaudeville, o opéra-comique, não eram temas de domínio literário, estético, da poética, mas sim político.

Em 1853, Adolphe Lacan, advogado da Corte Imperial de Paris, publicou o Traité de la Légis/ation et de la Jurisprudence des Théâtres (1853), um compendio das regras impostas aos teatros franceses desde o século XVII. Segundo ele, o início da formulação de uma legislação para a regulamentação teatral se tornou necessária a partir da abertura oficial da Ópera de Paris, em 1689.

Lacan, com a intenção de neutralidade das informações que se acredita ter a compilação de leis e normas forja a origem da Ópera de Paris a partir da união dos atores italianos, naturalizados franceses, com os atores franceses já atuantes nos teatros do país, sendo Pierre Perin (1620-1675) aquele que produziu a "primeira ópera" em língua francesa. Com música de Robert Cambert, Perin escreveu Pomode et La Pastorale d'Issy, estreada em 1659, no Hôtel de Monsieur de la Haye (NOINVILLE, 1757, pp.7781), a qual passou a ser considerada, por autores do século XVIII, a "primeira" ópera originalmente francesa, justamente por ter sido escrita em francês. 
Lacan continua delineando a cronologia legal do teatro francês afirmando que em 1659, Pierre Perin obteve a permissão de criar em Paris, e em outras cidades do reino, academias de música para cantar peças de teatro, "como se praticava na Itália, na Alemanha e na Inglaterra" (LACAN, 1853 , p. 349), por um período de doze anos, "com a autorização de cobrar do público o que ele achava justo e a proibição de quem quer que fosse de representar qualquer peça parecida ou música em verso na língua francesa sem o seu consentimento" (LACAN, 1853, p. 349).

A autorização real definia também que as óperas eram peças de música totalmente diferentes das comédias recitadas e que, por isso, os nobres (gentilshommes) e as damas poderiam cantar uma ópera, sem contraverter os títulos de nobreza, nem perder seus privilégios, direitos, imunidades, etc. (LACAN, 1853, p. 349). A permissão de exclusividade concedida a Perrin ainda não se constituía na estruturação de uma companhia de ópera estável, assim como a descrição dos possíveis atores, caracterizava-se apenas a organização de um divertimento de corte, em que fazer parte e assistir ao espetáculo ocupavam o mesmo patamar.

Enquanto Lully usufruía do privilégio sobre as Tragédies en Musique, cuja característica das obras com esse título era de um espetáculo considerado completo, abrangendo o texto, a música, o canto, o ballet, os maquinários e as vestimentas, foi concedido a Perin a exclusividade para a produção de espetáculos e obras aos moldes da ópera italiana, ou seja, um teatro integralmente cantado. A concessão deste tipo de privilégios não só garantia a exclusividade para o artista, mas, sobretudo, definia a obra, a forma na qual deveria ser estruturada. Assim, enquanto Lully tinha a autorização de realizar espetáculos com ballets, maquinários, orquestra, música e declamação e apresentá-los no teatro da corte, a Perin cabia os espetáculos totalmente cantados, cuja estrutura alternava recitativos e árias, mas com letra em francês, e estas apresentações aconteceriam em salas públicas e tinham como fonte de renda a venda de entradas para o público. 
Quanto aos artistas populares, tanto a falta de estabilidade dos grupos, a falta de regimentos internos e a convivência com direitos de atuação indeterminados, como a ausência de profissionalização do corpo artístico, condenava-os à marginalidade. As trupes de teatro popular eram nômades e seus artistas representavam qualquer tipo de papel seja o trágico ou o cômico, eram cantores, dançarinos, contorcionistas, ou o que mais a peça demandasse deles.

Embora trabalhasse com direitos adquiridos, o teatro de Ópera de Paris só alcançou certa estabilidade, em 1689, quando Jean-Nicolas de Francine (1662-1735) obteve a permissão do Rei Luís XIV para dar continuidade ao estabelecimento organizado por Lully e de estruturar a Academie Royale de Musique, em Paris e em outras cidades do reino. Outra ordem real, promulgada dia 21 de outubro de 1680, referente aos espetáculos inteiramente declamados reúne em um só grupo os comediantes do Hotel de Bourgogne e aqueles da Rua Guénégand. As duas trupes eram constituídas de artistas nômades e esta ordem do rei fazia destes comediantes membros de uma companhia fixa, dando origem ao Théâtre Français. Este decreto ainda concedia como privilégio as representações, em Paris, de peças totalmente declamadas, proibindo qualquer outra trupe de se apresentar na cidade sem uma ordem expressa do rei.

As intenções declaradas no documento legal para a união e concessão de privilégios a esses grupos de artistas se referia a "rendre les représentations des comédiens plus parfaites, par le moyen des acteurs et actrices auxquelselle a donné place dans la dite troupe" (LACAN, 1853, p. 296) ${ }^{6}$. Mas indiretamente estas ações também respondiam ao interesse crescente da nascente burguesia por estes espetáculos. De um lado, este público em formação criava um potencial lucrativo com a estabilização das companhias teatrais em acordos comuns com o Estado; por outro lado

\footnotetext{
6 "tornar as representações dos comediantes mais perfeitas, reunindo os atores e atrizes na referida trupe" (Tradução Livre).
} 
este público, ao se familiarizar com esse tipo de divertimento, passava a exigir mais e mais qualidade dos espetáculos que eram apresentados. $\mathrm{O}$ contexto que se coloca é de dupla formação, tanto da estruturação institucionalizada dos teatros, fato que interfere diretamente na elaboração estética das obras, como da formação do público pagante em espectador.

\section{Insurgências positivias}

A especialização do teatro e os regimentos teatrais regulamentadores do ofício do artista foram se aprimorando durante toda a primeira metade do século XVIII. Às margens do desenvolvimento dos teatros oficiais também se desenvolviam pequenos espetáculos colocados em cena durante o período de permanência das feiras sazonais na cidade de Paris.

Dois gêneros de teatro musical, o vaudeville e, posteriormente, o opéra-comique ${ }^{7}$, surgiram dos espetáculos populares apresentados nessas feiras parisienses, em um período de mudanças significativas na regência das artes teatrais francesa, marcado pelo falecimento de Lully e a expulsão dos artistas italianos do Hôtel de Bourgogne, no ano de 1697, os quais só regressariam à França em $1752^{8}$.

Estes gêneros se desenvolveram fora do circuito teatral de privilégios formado pela prática francesa de regulamentação artística imposta pelo governo aos teatros principais. Eles também não são oriundos do teatro de corte, cuja linguagem está atrelada às imposições do rei ou às exigências de uma plateia cortesã, são obras que tomaram

\footnotetext{
7 Por se tratar de um gênero de teatro musical, o termo opéra-comique, no decorrer deste texto, não será traduzido para o português, será empregado em francês e no masculino.

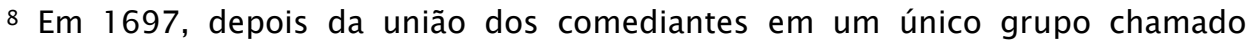
Comédie Française ou Théâtre Français, os artistas que se apresentavam na Foire Sant-Germain e na Foire Saint-Laurent começaram a utilizar o repertório do grupo italiano anteriormente instalados no Hôtel de Bourgogne.
} 
forma no meio urbano, elaboradas e apreciadas pela multiplicidade social e cultural que representava os frequentadores das feiras.

Tais espetáculos começaram a ganhar um caráter mais homogêneo nos últimos anos do século XVII, época em que a Foire Saint-Germain e a Foire Saint-Laurent eram as principais feiras parisienses. A primeira se localizava entre a igreja de Saint Germain de Prés e a Saint Suplice (rive gauche) e funcionava entre o início de fevereiro até o domingo de páscoa; a segunda ficava nas proximidades do faubourg Saint Denis (rivedroite) e permanecia aberta entre agosto e outubro. Os espetáculos oferecidos eram bastante variados, como descreve Brazier (1837) em sua crônica dos teatros de Paris, com a apresentação de saltadores e dançarinos em cordas, monstros, gigantes, anões, animais adestrados conhecidos como animaux savants, marionetes, figuras de ceras e jogos de feira. Com o passar do tempo, esse tipo de divertimento foi dando lugar às pequenas comédias em prosa ou verso entremeadas por música, conhecidas posteriormente como vaudeville.

No entanto, o termo vaudeville já era utilizado anteriormente ao seu emprego nas feiras parisienses e detinha um significado muito mais abrangente do que o utilizado no século XVIII e XIX. Dizia-se vaudeville as pequenas canções que satirizavam os acontecimentos diários ou anedotas escandalosas, bastante populares no interior do país. A característica que marcava tais canções era a sua finalização com couplets que os artistas cantavam sucessivamente. Estes trechos musicais não faziam parte da ação, funcionavam apenas como forma de ênfase a determinado assunto, reforçando a dramaticidade da narrativa.

De simples canções o vaudeville passa a designar, a partir do final do século XVII, peças satíricas curtas, entremeadas de música. A simplicidade e facilidade dos versos que formavam os trechos musicais faziam com que fossem facilmente aprendidos pelo público, 
memorização dada principalmente por sua característica musical ${ }^{9}$, eram parodias de árias operísticas de sucesso representadas na Académie Royale de musique, possibilitando à plateia seguir acompanhando os atores nas repetições subsequentes do trecho cantado.

A visibilidade destes espetáculos aumentou no decorrer do século XVIII, considerando a progressiva estabilização da estrutura das peças apresentadas, marcadas por textos críticos, em linguagem popular e entremeados por música. O sucesso dos vaudevilles em cena nas feiras deflagrou a reação dos teatros parisienses detentores dos direitos de representação de gêneros teatrais específicos, a Comédie Française e o Opéra. As ameaças dessas composições aos teatros principais eram entendidas em duas dimensões: a apropriação das linguagens artísticas autorizadas àqueles espaços - a representação falada de um e o canto e danças do outro - e a competição pelo público. Os espetáculos das feiras parisienses recebiam em sua plateia pessoas das mais diversas esferas sociais, tornando-se concorrência direta às outras salas de espetáculo.

A apresentação dos vaudevilles era condicionada à frequência das feiras, esta característica somada à instabilidade dos grupos artísticos que os representavam, mantinham tais peças às margens das leis impostas pelo Estado aos teatros reconhecidos como salas de espetáculo oficiais e aos artistas ligados a eles. As apresentações das feiras não eram tidas como espetáculos formais, apenas espaços onde eram colocados em cena divertimentos itinerantes. O lugar social de invisibilidade no qual o vaudeville se encontrava, enquanto expressão artística, abria caminhos para a liberdade de criação de seus artistas.

Todavia, tanto a rivalidade surgida das disputas pelo público quanto também a contrariedade ao espaço de desvio às regras no qual se enquadrava o vaudeville, levaram esses espetáculos a serem alvo de proibições e sanções durante todo o século XVIII, ora de ter partes

9 Maurice Halbwachs buscou refletir sobre o processo da memória musical e da memória social e individual apoiada em músicas, no último capítulo de sua obra A memória Coletiva. 
cantadas, ora de utilizar ballets, danças, maquinarias e decoração. Estas interdições intervinham diretamente na obra e não na sala de espetáculo e suas práticas, era a forma estrutural do vaudeville que sofria modificações a cada sanção, reforçando o caráter de resistência deste teatro urbano frente às imposições do Estado, tomado desde o início de suas representações e sustentado pelos compilados de sua história, publicados no século XIX, como aparece nas obras de Émile Campardon (1877) ou Nicholas Brazier (1837).

A representatividade do público também era distinta nas práticas estabelecidas nos espetáculos das feiras em comparação aos grandes teatros de Paris. Nos teatros regulares até o século XVIII havia a preocupação com o julgamento da peça apresentada por um seguimento do público, a aristocracia, acomodada nos camarotes reais, cujo angulo de visão do palco era mais favorecido. Esta postura está impressa na arquitetura dos teatros do período, que privilegiava a visão e permitia maior interação das camadas mais abastadas da sociedade com os atores no decorrer do espetáculo. Nesses teatros periféricos o parterre, ou a plateia, não possuía grande visibilidade considerando a altura do palco e a aglomeração das pessoas que permaneciam em pé durante todo o desenrolar da apresentação. Foi apenas em meados do século $\mathrm{XVIII}$ que as salas dos teatros começaram a ganhar novas estruturas, novos formatos, dando melhores condições de visibilidade e conforto para a plateia, composta majoritariamente de burgueses, estudantes, intelectuais e pessoas de menor renda (BARTHÉLÉMY, 1990, pp. 145148).

As feiras, por serem sazonais, não dispunham da estrutura física dos teatros principais, os quais eram divididos entre os camarotes e o parterre, marcadores impostos pela arquitetura dos locais de hierarquização social. Os espaços para espetáculos existentes nas feiras, conhecidos como loges, eram espaços fechados por pranchas de madeira, onde se colocavam cavaletes verticais para que as pessoas se 
acomodassem (BRAZIER, 1837, 123). Sem as subdivisões físicas do espaço do espetáculo, o público se tornava heterogêneo, colocando todos aqueles que formavam a plateia em um mesmo nível, independente da distinção social. Este arranjo permitia ao público se expressar de maneira singular, se não da mesma forma, com a mesma intensidade dos camarotes da aristocracia dos grandes teatros.

A ausência de distinção entre as vozes da plateia das feiras desequilibrava os jogos de poderes e forças políticas estabelecidos nos teatros principais, singularidade que causava incômodo, visto as relações determinadas entre o teatro e o público, no decorrer do século XVIII. O comportamento da plateia se regia pelo papel do teatro no seio desta sociedade, o qual era o lugar de representação do ser público em um período que vivia a estruturação dos lugares do público e do privado. $\mathrm{O}$ teatro funcionava como o recinto de encontro e de expressão das relações sociais ocorridas fora do palco.

Para esse período, uma peça não simbolizava a realidade, ela a criava através das convenções da realidade (SENNETT, 1988, p. 106). A compreensão se dava por sinais mais que por símbolos, não se procurava os significados implícitos em uma fala ou em um ato, o significado inteiro estava presente no que era dito e em um gesto. Para o público, o ator em cena representava a "verdade" de sua expressão e não um texto literário.

A compreensão de sinais mais que de símbolos, explicada por Sennett, torna inteligível a reação e a repulsa das classes mais abastadas aos espetáculos das feiras, pois estes artistas punham em cena temas do cotidiano e de práticas comum às pessoas pertencentes aos mais diversos níveis sociais. Os textos possuíam uma linguagem direta, menos poetizada e a gesticulação utilizada em cena fugia às convenções costumeiras daquelas dos grandes teatros e tendia ao caricato.

A maneira de representar assustava enquanto sinal da realidade existente. Por outro lado, estes espetáculos eram representantes da mentalidade daquele meio, buscavam a caracterização das relações 
sociais ali existentes como forma de crítica ou simplesmente para ressaltar a hilaridade que determinadas posturas ou feitos já provocavam, as quais ficavam mais visíveis quando realizadas por um ator em cena. Em uma vida organizada por convenção abstrata e impessoal, era o palco que abrigava a regra de discurso mais apurada da sociedade do século XVIII.

A percepção do mundo por sinais permitia que a emoção da plateia se misturasse à exposta no palco, esvaecendo os limites entre o real e o texto literário, este sentido era reforçado, nas apresentações de vaudeville, pela proximidade público-palco no espaço da sala e também na encenação, a qual dependia da participação ativa da plateia na repetição dos couplets, para que a força dramática da obra ganhasse sentido. No decorrer da peça, a plateia se tornava envolvida e, de certa forma, no controle da ação, interferindo diretamente na atuação dos atores. Esse comportamento faz com que essas obras não se constituam apenas do texto e da interpretação dos atores, mas tenham como parte fundamental a reação do público, cuja intenção direciona o sentido final da obra.

A interação do público com o espetáculo é o que garantia a sobrevivência dos espetáculos das feiras. A crescente estabilização do formato das apresentações dadas nas feiras parisienses, priorizando a apresentação de peças vaudevilles, e a especialização dos artistas e autores que lá trabalhavam, foram pontos fundamentais no aumento da plateia e na popularidade alcançada por este tipo de teatro musical. 0 êxito deste espetáculo popular se contrapunha aos espaços de ação dos teatros principais, por isso ameaçavam tanto suas receitas quanto sua força representativa e também sua estabilidade estética.

Como detinham privilégios concedidos pelo Estado, os teatros principais se utilizaram deles para tentar coibir as apresentações das obras vaudevilles nas feiras. Tais interdições são calcadas no proibido, demarcando a exclusão e, assim, possibilitando a utilização de tudo o 
que não estava incluso nelas como possível, criando novos caminhos a partir da opressão.

Dessa forma, apesar de, em 1706, a Comédie Française ter conseguido que o Lieutenant Général de Police proibisse os teatros das feiras de utilizarem diálogos, em 1708, a viúva de Maurice e Alard conseguiu por meio do pagamento de uma taxa a autorização do teatro de l'Opéra para utilizarem a troca de cenário, de cantores e de dançarinos no decorrer das peças (CAMPARDON, p. 87). Mas, anos depois, em 1709, uma nova ordem comandada pela Comédie Française proíbe os teatros das feiras de utilizarem ballets, danças, maquinarias e decoração.

Não contentes com a permanência dos espetáculos mesmo após as últimas proibições, a Comédie Française pede que fosse proibida toda forma de diálogo e de monólogo. Em resposta à imposição da supressão dos diálogos e das árias das obras apresentadas, os artistas forains criam a "pièces à lamuette", nas quais os atores subiam em palco e gesticulavam a intenção de cada cena, o texto que não podia ser dito era apresentado em cartazes erguidos para o público que cantava, acompanhado pela orquestra, os refrãos dos vaudevilles. Dessa forma, eles cumpriam a determinação de não utilizarem na peça nem falas, nem partes cantadas pelos artistas, mas mantinham o espetáculo em funcionamento, subvertendo as imposições externas. Ao contrário de desestabilizar o teatro como se pretendia, a estratégia para contornar a proibição criou novos caminhos de expressão, enfatizando a participação do público, parte fundamental da obra, ao cantar os trechos de paródias musicais no lugar dos artistas.

Após várias tentativas de dificultar as apresentações de vaudevilles, em 26 de dezembro de 1714, Catherine Baron e Gauthier de Saint-Edme, dois artistas das feiras, conseguiram a autorização para colocar em cena peças de teatro musical, denominadas por eles de Opéra-Comique. Respaldados por esta concessão, eles passaram a dirigir duas companhias de atores: a Opéra-Comique de Dominique e a 
NouvelOpéra-Comique de Baxter e Saurin ou Bel Air. Mesmo depois de conseguirem a autorização para continuar representando peças de teatro entremeadas com música não original, entre os anos de 1719-1721 e 1722-1723, os artistas forains foram obrigados a paralisar suas atividades cênicas, sendo permitida em suas instalações apenas a apresentação de danças, malabares de corda, além de teatro de marionetes.

Apesar das constantes proibições, estes teatros se mantinham firmados na tradição já consolidada do vaudeville. Estas peças, criadas originalmente para os espetáculos das feiras, eram produzidas em grande quantidade, visto o número de apresentações oferecidas, tanto que constituíram um extenso acervo de material teatral ainda no início do século XVIII, possibilitando a publicação, por Lesage e d'Orneval em 1737, de libretos e partituras de vaudevilles em nove volumes, numa coletânea denominada Théâtre de la Foire. Dois anos depois, esta coletânea já estava na sétima edição, indicando a difusão deste gênero teatral francês. A popularização dos vaudevilles não se restringia ao espaço das feiras, passaram a estarem presentes tanto no meio público quanto no privado, valendo-se das publicações de libretos ou de compêndios como o organizado por Lesage e d'Orneval. O tom de sátira e crítica social contidas nessas peças, as quais eram formuladas no vasto espaço de discurso que se contrapunha ao controle estrito à proibição, encorpava a voz de um público teatral em modificação e cada vez mais receado por aqueles que detinham as concessões do poder.

Sua posição de insurgência face aos regulamentos teatrais e privilégios concedidos ao Opéra e à Comédie Française demarcou um lugar de expressão insigne frente aos demais. As anuências teatrais pautadas nos formatos e estruturas das peças apresentadas fundiam os sentidos e representações dos teatros e das obras em um só. Falar do Ópera significava falar das obras cênicas inteiramente cantadas, à Comédie Française cabia comédias e tragédias inteiramente declamadas 
e ao se referir aos teatros das feiras se referia às peças cômicas ou satíricas, cuja estrutura comum apresentava partes faladas e trechos musicados. Sendo assim, foi o significado representativo da obra que possibilitou o retorno do teatro Opéra-Comique, a pedido da prefeitura de Paris, detentora dos direitos do teatro Ópera, após nova suspensão das apresentações entre 1744 e 1745. Logo depois da reabertura do teatro, os privilégios de representar obras mistas entre canto e fala são vendidos a Jean-Monnet (LEGRAND, 2002, p. 78-82). Ele constrói uma luxuosa sala na Foire Saint-Laurent, com projeto de Arnoult, engenheiro-maquinista do rei, e decoração do interior feita pelo pintor do rei, Boucher, para abrigar o novo teatro de Opéra-comique.

O embate trazido pela Querelle des bouffons, nos anos subsequentes à retomada do Opéra-Comique, o qual foi desencadeado pela representação de La Serva padrona, de Pergolèse no teatro Ópera, contrapôs a forma e características da tragédie en musique francesa, representada pelas obras produzidas pelo Ópera e à ópera bufa italiana. Nesta discussão, que contou com forte partidarismo e debates filosóficos sobre os limites do teatro lírico francês, o vaudeville e as novas obras originais apresentadas no teatro Opéra-Comique não ganham muito destaque. Aproveitando o desvio das atenções e a desestruturação da credibilidade estética do tragédie en musique francês, provocado pelo debate partidarista entre teatro lírico francês e italiano, o opéra-comique inova e escapa às delimitações de gênero que permitiam o funcionamento do teatro, as quais determinavam que apenas poderiam ser apresentadas peças declamadas, entremeadas de música não original.

Neste contexto de menor rigidez e atenção às estruturas formais das obras dos teatros marginais, em 30 de julho de 1753, apresentou-se na Foire de Saint-Laurent a peça Troqueurs, com libreto de Vadé e música de Dauvergne, primeira opéra-comique com música inteiramente original. Dessa forma, de teatro declamado entremeado de música não original e estrutura simples, os artistas do teatro Opéra-Comique, como 
o compositor François-Andre Philidor e o libretista Michel-Jean Sedaine, começam a conceber peças com formato musical mais elaborado, chamadas de ariettes, ou seja, árias curtas e de caráter ligeiro inspiradas, sobretudo, na estrutura das árias de ópera italiana.

As obras com este formato foram chamadas de opéra-comique en ariettes. Além de serem estruturadas com partes musicais compostas originalmente para elas, passa a haver um maior equilíbrio em sua estrutura, entre as partes faladas e os trechos cantados. A música também passa a ser concebida como acompanhamento para as ações dos atores, constituindo uma obra mais uniforme em sua proposta de utilização da música como parte fundamental da dramaticidade da narrativa.

O opéra-comique en ariettes, para Legrand (2002), inaugura uma nova sensibilidade, desenvolvendo a emoção nas obras, assim como a sátira social. Este novo gênero teatral chama a atenção dos philosophes e literatos. Diderot, em Le Neuveu de Rameau, mostra especial interesse nesta nova formula do opéra-comique, dizendo que há nestas obras toda forma de características; uma verdadeira infinidade de declamações: "Cela est sublime; c'est moi qui vous le dis", diz Diderot (2001, p.76).

Em 1762, a Comédie Italienne adquire do Ópera os direitos sobre o teatro de Opéra-Comique, engajando-se a pagar o montante anual de 40 mil livres à Académie Royale de Musique (VENDRIX, 1992, p. 57). Com este acordo, uniu-se no Hôtel de Bourgogne, com o nome de Théâtre Italien, os artistas e o repertório da trupe italiana e da companhia do teatro de Opéra-Comique, evento que marca a saída do teatro de opéracomique das feiras, garantindo sua definição como gênero distinto do vaudeville.

A disputa legal pelo direito de representação teatral continua em 1779, quando um decreto do Conselho de Estado proíbe que as comédias em língua italiana fossem representadas no Hôtel de 
Bourgogne, expulsando também os atores italianos. Os artistas franceses, provenientes do teatro das feiras, retomaram as apresentações colocando em cena peças em francês. Em conformidade com esse ato, em 31 de março de 1780, outro decreto impõe o título de Opéra-Comique em substituição ao de Comédie Italienne à companhia do Hôtel de Bourgogne (TROTT, 2000). O período no qual as companhias italiana e francesa permaneceram unidas causou grande impacto na linguagem poética do gênero opéra-comique, aproximando a estrutura musical elaborada pelos artistas franceses daquela utilizada pelos italianos nas ópera bufas. O caráter ligeiro dessas obras musicais não delimitaram o gênero opéra-comique à sátira ou ao cômico, principalmente nas composições de André-Érnest Grétry.

A sujeição dos artistas e de suas obras às regras do Estado foi colocada de maneira austera até o início da década de 1790. Até a última década do século XVIII, o funcionamento dos teatros estava condicionado à estrutura das obras que eles colocavam em cena, por regras de funcionamento ou estrutura do espaço de apresentação, fixando e enrijecendo a forma de escrita das obras, mais do que selecionando o público que as assistia. Entretanto, depois da Revolução de 1789, há uma flexibilização nas regras que regiam o funcionamento das salas de espetáculo. Em 13 de janeiro de 1791, a Assembleia Nacional proclama a liberdade dos teatros (TISSIER, 1992). O artigo $1^{\circ}$ anuncia que "Tout citoyen pourra élever un théâtre public et y faire représenter des pièces de tous les genres, en faisant, préalablement à l'établissement de son théâtre, sa déclaration à la municipalité des lieux" (LEGRAND, 2002, p. 231)10. Com essa resolução diversos estabelecimentos foram abertos oferecendo os mais variados gêneros de espetáculo. Desde a liberdade completa promulgada por decreto nacional, foram inaugurados 51 teatros em Paris.

10 "Todos os cidadãos poderão fundar um teatro público, onde poderão representar peças de todos os gêneros, fazendo, anteriormente ao estabelecimento de seu teatro, sua declaração ao município de direito" (Tradução Livre). 
Na visão de Patrick Taïeb (1995), a lei que vetava as corporações e seus privilégios e que deu liberdade aos teatros, promulgada por Isaac-René-Guy Le Chapelier, estendia aos espetáculos o princípio do liberalismo econômico no qual o perfeccionismo das artes está ligado diretamente à concorrência entre os teatros. No entanto, o efeito proveniente desta disposição se manifestou paralelamente a ela. A rápida multiplicação das salas de espetáculos, as condições desastrosas com as quais elas se colocaram em concorrência e a atribulação da vida política que proporcionou a dispersão do público das grandes instituições foram as causas principais do fechamento de muitos dos teatros abertos no período.

Mesmo com a liberação dos teatros e a autorização da livre abertura de salas de espetáculo, ainda havia controle sobre eles. Em julho de 1801, os teatros Feydeau e Opéra-Comique da sala Favart foram reunidos, mediante ordenação do Estado, e se instalaram na sala do Teatro Feydeau. O mesmo artigo que unia os artistas dos dois teatros fixava também a orquestra em um regente, seis primeiros violinos, 6 segundos violinos, quatro violas, seis violoncelos, quatro contrabaixos, duas flautas, dois oboés, dois clarinetes, quatro trompas, dois fagotes, uma harpa (LEGRAND, 2002, p. 234).

A saída do teatro Opéra-Comique das feiras e sua união com a companhia italiana fez com que um gênero teatral se desenvolvesse separadamente e de maneira distinta dos vaudevilles, os quais continuaram a ser representados nos pequenos teatros e por trupes itinerantes. Entre 1762, quando o Opéra-Comique se uniu ao teatro italiano, até o início do século XIX, os gêneros opéra-comique e vaudeville se distinguiram na forma e na concepção estética de suas obras, mas mantiveram como base de distinção a utilização do canto e da fala entremeados em uma mesma obra.

Neste período de menor regulamentação legal, vários teatros passaram a representar o mesmo gênero de peça e todas as noites da 
semana eram oferecidos espetáculos nos mais variados valores e níveis de qualidade. Foi concedida a permissão de apresentar o gênero vaudeville para o Théâtre Ventadour, o Gymnase Dramatique, o Théâtre du Vaudeville; o Théâtre du Palais-Royal; o Théâtre de la Port-SaintMartin; o Théâtre de l'Ambigu-Comique; o Théâtre de la Gaité; o Théâtre des Folies Dramatiques; o Théâtre de la Porte Saint-Antoine; o Théâtre du Panthéon e o Théâtre du Luxembourg. Enquanto o vaudeville foi patrimonializado como expressão popular francesa, permitindo que várias salas de espetáculo apresentassem peças deste gênero, o opéracomique se especializou como linguagem teatral singular, deixando de pertencer ao popular e passando a pertencer à categoria de teatro real, sendo permitido que as obras classificadas como tal fossem apresentadas apenas no Théâtre Royal de I'Opéra-Comique (ROURIÈRE, 1837).

As peças de opéra-comique já separadas como gênero superior, são oficialmente definidas pelo decreto de 8 de junho de 1806 , o qual determinava as regras para formação de repertório de cada um dos teatros reais. $\mathrm{O}$ artigo $4^{\circ}$ do decreto diz que o repertório do Opéra, da Comédie-Française e do Opéra-Comique seria determinado pelo ministro do interior e nenhum outro teatro poderia apresentar em Paris as peças que faziam parte do repertório desses três grandes teatros sem autorização e sem pagar uma retribuição instituída em comum acordo e com a autorização do ministro ${ }^{11}$. O mesmo texto ainda determina, no artigo $8^{\circ}$, que nenhuma companhia itinerante poderia existir sem a autorização dos ministros do interior e da polícia.

A definição de repertório caminha de acordo com a crescente valoração da autoria e da posse intelectual. Mas, no caso específico dos teatros de Paris, e, sobretudo, em relação aos teatros musicais, esta imposição também visava a proteção das características das expressões

11 "Les Théâtres - lois - règlements - instructions - salle de spectacle - droits des auteurs - correspondants - congés - début - acteurs de Paris et de département .Paris : Chez alexis Eymery, 1817. 
teatrais consideradas de origem francesa, como forma de distinção identitária em relação aos teatros de outras localidades da Europa, em especial à ópera Italiana e a ópera e ao singspie/germânicos.

Como a preocupação principal era garantir as características específicas das obras postas em cena, a fim de definir e salvaguardar as singularidades de cada sala de espetáculo, em 25 de abril de 1807, são promulgadas as definições do que viria a ser o repertório de cada teatro, para que o decreto editado em 1806 pudesse ser cumprido. Esse decreto divide os teatros em "Grands théâtres" e "théâtres secondaires". $\mathrm{O}$ artigo $1^{\circ}$ determina os gêneros dos considerados Grands théâtres, os quais atuariam conforme as prerrogativas ligadas a este título. De acordo com as novas determinações, o primeiro era o Teatro Francês (Teatro de S. M. O Imperador) especialmente consagrado à tragédia e à comédia, como às comédias representadas nos teatros ditos italianos, até o estabelecimento do Opéra-Comique. O teatro da Imperatriz (Odéon) foi considerado como anexo do Teatro Francês, onde poderia ser representadas apenas comédias. O segundo era o Teatro da Ópera (Académie Impériale de Musique), especialmente consagrado ao canto e à dança. Seu repertório seria composto de todas as obras, tanto "óperas (peças inteiramente em música) quanto ballets (do gênero nobre e gracioso)". O terceiro teatro era o Teatro de Opéra-Comique (Teatro de S. M. Imperador), destinado à representação de toda espécie de comédias e dramas mêlés de couplets, de ariettes e de moreceau d'ensemble (entremeados de peças musicais). A Ópera Bufa é classificada como um anexo do Opéra-Comique, onde só poderiam ser representadas peças escritas em italiano (LACAN, p.432-433).

O teatro do Vaudeville, nesta nova ordem, passa a ser considerado como o primeiro entre os teatros secundários e seu repertório deveria conter apenas pequenas peças entremeadas de couplets, escritas com base em áreas conhecidas e paródias (LACAN, p. 434). Além do teatro do Vaudeville, completavam a lista dos teatros secundários o Théâtre des 
Variétés, o Théâtre de la Porte-Saint-Martin e o Théâtre dit de la Gaîté. No entanto, em julho de 1807 , um novo decreto reduziu definitivamente o número de teatros de Paris para oito: L'Opéra; Le Vaudeville; Théâtre Français; Les Variétés-Montmartre; Feydeau; La Gaieté; L'Odéon; L'Ambigu. Todos os outros teatros deveriam ser imediatamente fechados.

Apenas no ano de 1830, o teatro Vaudeville conquista o título de Théâtre National, depois do sucesso alcançado enquanto estava sob a direção de Étienne Arago, e da crescente exploração desse espetáculo por autores diversos, os quais o considerava expressão genuína da arte francesa, como por exemplo Nicolas Brazier e sua insistência na prosperidade do teatro Vaudeville: "Eh bien! jamais les grands théatres ne se sont trouvés dans un état plus prospère" (BRAZIER, p. 175). A mudança de status de teatro menor a teatro representante do nacional, seja para o vaudeville quanto para o opéra-comique, enquanto gêneros cênicos musicais, está inserida em um momento de mudanças sociais e culturais decisivas, como a ânsia por forjar uma identidade nacional, a estruturação do Estado e a imposição das regras cabíveis aos teatros considerados educadores para a civilidade e a própria transformação do papel das artes na sociedade, da transformação das relações do público com o espetáculo, do autor com a obra, da obra com o executante.

De maneira geral, as regras impostas aos teatros delinearam elementos específicos de estrutura para as peças representadas naqueles espaços. No caso particular do vaudeville e do opéra-comique, a invisibilidades desses espetáculos em sua origem propiciou a eles gerar mudanças na forma de concepção do teatro musical, tornando-se espaço de expressão e criação. Contrapondo-se às leis impostas, estes artistas deram origem a gêneros cênicos musicais subversivos, mas provenientes da expressão popular, com linguagem e temas voltados às camadas sociais excluídas dos teatros principais. Apenas no século XIX os dois gêneros passam a ser representativos de Teatros do primeiro escalão, subvencionados pelo governo. Todavia, sua origem fundada em 
insurgências permanece no caráter de experimentação artística e poética que marca estes dois gêneros de teatro musical até o final do século XIX.

\section{Fontes}

BOILEAU, Nicolas. Art poétique. Paris: Editeur Denys Thierry, 1674.

BRAZIER, N. Chroniques des petits théâtres de Paris depuis leur créations jusqu'à ce jour. Paris : Aladin Librairie, 1837.

CAMPARDON, Emile. Les Spectacles de la Foire depois 1595 jusqu'à 1791, Paris, Berger-Levrault, 1877.

DIDEROT, Jacques. Le neveu de Rameau. Paris: Librairie Générale Française, 2001 ( ${ }^{\text {a }}$ publicação 1805).

FAVART. Theatre de M. Farvart, ou Recueil des comédies, parodies etopéras-comiquesqu'il a donnésjusqu'àcejour. Paris :Duchesne, 1763.

LACAN, Adolphe. Traité de la Législation et de la Jurisprudence des Théâtres. Paris : Éd. Durand, 1853.

Les Théâtres - lois - règlements - instructions - salle de spectacle droits des auteurs - correspondants - congés - début - acteurs de Paris et de département. Paris : Chez alexis Eymery, 1817.

LESAGE, Alain-René e D'ORNEVAL. Le Théâtre de laFoire ou l'Opéracomique. Vol. I. Paris, Gandouin, 1721-1737.

NOINVILLE, Durey de, Histoireduthéâtre de l'Académieroyale de Musique en France, Paris, Duchesne, 1757, vol. I, pp. 77-81. 
ROURIÈRE, M. Histoiredesthéâtresetdeslieus d'amusemenspublics de Paris. Paris :Librairiedesétrangers, 1837.

SOLIÉ, Émile. Histoire du théâtre royale de l'Opéra-Comique. Paris : chez tous les libraires, 1847

\section{Bibliografia}

BARA, Olivier. Le théâtre de l'Opéra-comique sous la Restauration, Enquête autour d'un genre moyen. Olms :Hildeshim, 2001.

BAKHTIN, M. A Cultura Popular na idade Média e no Renascimento, Hucitec, 1999.

BARNES, Clifford Rasmussen. The "Théâtre de la Foire" (Paris, 17671762) : Its music and composer., Ph. D, University of Southern California, 1965.

BARTHÉLÉMY, Maurice. Métamorphoses de l'opéra français au siècle des Lumières. ActesSud - janvier 1990.

BURKE, PETER. Cultura Popular na Idade Moderna. Cia das Letras, 2010.

BOUSSOU, Silvie. Vaudeville et distanciation dans l'opéra-comique des années 1750, La Querelle des Bouffons dans la vie culturelle française du XVIIIe siècle, Paris : CNRS éditions, 2005.

COUVEUR, Manuel; VENDRIX, Philippe. L'opéra-comique en France au XIX siècle, Liège : Madarga, 2008. 
DARNTON, R. Censores em ação. São Paulo: Cia das Letras, 2016.

FABIANO, Andréa. La Querelle des Bouffons dans la vie culturelle française du XVIIIe siècle. Paris : CNRS éditions, 2005.

FRIEDLAND, Paul. Political Actors : Representative Bodies and Theatricality in the Age of the French Revolution, Ithaca et Londres, Cornell University Press, 2002

FUCHS, Max. La Viet héâtrale en province au XVIIle siècle, Paris, Droz, 1933.

GALLAND, Bruno. Archives de l'Opéra-comique et la comédie-vaudeville auX XVIIe et XVIIIe siècles. Nationales, 1992.

HABERMAS, Jürgen. Mudança Estrutural da Esfera Pública: investigações quanto a uma categoria da sociedade burguesa. Rio de Janeiro: Tempo Brasileiro, 1984.

HUNT, Lynn. Politics, Culture, and Class in the French Revolution. University of California Press, 1984.

KOSELLECK, R. Le Règne de la Critique. Les éditions de minuit, 1979.

JOHNSON, James H., Listining in Paris: A cultural History, Berkeley et Los Angeles, University of California, Press, 1995.

LAGRAVE, Henri. Le théâtre et le public à Paris de 1715 à 1750, Paris, Klincksieck, 1972. 
LANSON, Gustave. "Programme d'études sur l'histoire provinciale de la vie littéraire en France", Révue d'histoire moderne et contemporaine, vol. $4, n^{\circ} 7$.

LEGRAND, Raphaëlle. Regards sur l'opéra-comique: trois siècles de vie théâtrale. Paris : CNRS Editions, 2002.

LEGRAND, R. ; TAIIEB, PATRICK. L'Opéra-comique sous le consulat et I'Empire. PRÉVOST, Paul (org). Le théâtre lyrique en France au XIXe siècle. Paris : Ed. Serpenoise, 1995.

RAVEL, Jeffrey S. "Des définitions aux usages: une historiographie du théâtre français au XVIIIle siècle". Parlement(s), 8 (sept. 2012).

ROUGEMENTO, Martine de. La vie théâtrale en France au XVIIIe siècle. Paris, Honoré Champion, 1988.

ROUSSEAU, J. J., verbete: Vaudeville. Dictionnaire de la musique. In : CEuvrescomplètes. Vol. 5. Paris: éd, Bernard Gagnebin et Marcel Raymond, Gallimard, 1995.

SENNETT, R. O declínio do homem público: as tiranias da intimidade. São Paulo: Cia das Letras, 1988.

TAÏEB, PATRICK. "L'Opéra-comiquesousleconsulat et l'Empire”. PRÉVOST, Paul (org). Le théâtrelyrique en France au XIXesiècle. Paris: Ed. Serpenoise, 1995

TISSIER, André. Les Spectacles à Paris pendant la Révolution. Répertoire analytique, chronologique et bibliographique. De la réunion des États généraux à la chute de la royauté, 1789-1792. Genève: Droz, 1992. 
TROTT, David. Théâtre du XVIIIe siècle, Jeux, écritures, regards. Montpellier : Ed. Espace 34, 2000.

VENDRIX, Philippe. L'Opéra-comique en France au XVIIle siècle. Liège: Mardada, 1992 